\title{
"STANDING ON THE SHOULDERS OF A GiANT"
}

\author{
NICOLAS P. TERRY*
}

It was a great honor when Eleanor passed me the keys to the William S. and Christine S. Hall Center for Law and Health. Her handoff of the Center was generous. I also was first treated to meals at her favorite breakfast and lunch places in downtown Indianapolis"

The Hall Center was established in 1987 and in 2003 the first edition of the Indiana Health Law Review was published. By 2011, the Hall Center was a vibrant place. The core components of a leading health law program were already in place: a strong health law curriculum; a national ranking; interdisciplinary links across campus to public health, bioethics, and social work via then colleagues Eric Wright and Eric Meslin, and our current valued colleague Heather McCabe; a strong relationship with our friends at Hall Render; and, of course, a reputation for excellent health law research and scholarship.

These days I would be viewed by health law professors as having been brought up on the wrong side of the tracks. I came from a background of medical malpractice and products liability, with the occasional sprinkling of bioethics and third-party insurance. When I first met Eleanor, heard her talk, and read her scholarship, I experienced a very different branch of health law - the doctrine rooted in administrative law and the policy rotating around health care financing. This was the immense contribution Eleanor and a small group of like-minded folks brought to the then-fledgling health law academy in the 80s and early 90 s.

Of course, Eleanor's instincts and passions were accurate. Today, when I teach my health law and policy course, torts and bioethics issues are shuffled to the last three weeks of the semester, and the vast majority of the course is dominated by the issues Eleanor championed - health care financing, public and private health insurance, and inevitably, administrative rule-making.

Her scholarly output was extraordinary - even in retirement. I counted half a dozen books, twenty-six articles in refereed journals, over fifty articles in law reviews, and another thirty book chapters, book reviews, and so on. I didn't have the energy to count all her conference presentations.

The foundations for this scholarship are not hard to discern; her years at the Department of Health and Human Services and, previously named the American Hospital Association, must have been extraordinary. Just imagine being there as healthcare and Medicaid started to gain a civil rights lens or being a party to the earliest proposals for major health law reform.

Even a cursory look at some of the titles of Eleanor's work show the cutting edge, even prescience of her scholarship: Hard Choices under the Medicare Prospective Payment System from 1986; $;^{1}$ National Coverage Policy under the

* Hall Render Professor of Law, Executive Director, Hall Center for Law and Health, Indiana University Robert H. McKinney School of Law. Email: npterry@iupui.edu. My thanks to Anthony Singer, JD/MPH candidate for his editorial assistance.

1. Eleanor D. Kinney, Making Hard Choices Under the Medicare Prospective Payment System: One Administrative Model for Allocating Medical Resources under a Government Health Insurance Program, 19 IND. L. REV. 1151 (1986). 
Medicare Program: Problems and Proposals for Change from $1988 ;^{2}$ Rule and Policy-Making Under the Medicaid Program: A Challenge to Federalism in 1990. ${ }^{3}$ All of these topics could be torn from the headlines on today's health policy blogs!

Also, there was her teaching and the tremendous regard in which she was held by her health law students. Surely, it's impossible to overestimate her impact on her students in the early 1980s; a brilliant woman as scholar, teacher, and mentor.

Those of us in the health academy today should ponder the words of Isaac Newton in a letter to his Robert Hooke, in 1676:

"What Descartes did was a good step. You have added much several ways, and especially in taking the colours of thin plates into philosophical consideration. If I have seen a little further it is by standing on the shoulders of Giants."

Eleanor was a health law giant. For that I thank her, IU McKinney School of Law thanks her, the Hall Center thanks her, and her countless health law students loudly shout their appreciation!

2. Eleanor D. Kinney, National Coverage Policy Under the Medicare Program: Problems and Proposals for Change, 32 ST. Louis U.L.J. 869 (1988).

3. Eleanor D. Kinney, Rule and Policy-Making Under the Medicaid Program: A Challenge to Federalism, 51 Oнiо ST. L.J. 855 (1990). 